\title{
Evaluation of the Cytotoxicity of Two Cameroonian Herbal Plants of Genus Triumfetta rhomboidea and Dorstenia elliptica Using the MTT and Neutral Red Assays
}

\author{
Tembe-Fokunang Estella ${ }^{1}$, Fokunang Charles ${ }^{1, ~ *, ~ H o a r e ~ G a r y ~}{ }^{2}$, Salwa Barkwan $^{2}$, \\ Ngameni Bathelemy ${ }^{1}$, Tsague Marthe ${ }^{3}$, Paul Tomkins ${ }^{2}$, Nwabo Kamdje Armel Herve ${ }^{3}$, \\ Ngadjui Bonaventure ${ }^{2}$ \\ ${ }^{1}$ Department of Pharmaceutical Sciences and Traditional Pharmacopoeia, University of Yaoundé 1, Yaoundé, Cameroon \\ ${ }^{2}$ Centre for Biopolymer and Bio-molecular Research, Athlone Institute of Technology, Athlone, Republic of Ireland \\ ${ }^{3}$ Department of Biomedical Science, University of Ngaoundere, Ngaoundere, Cameroon
}

Email address:

charlesfokunang@yahoo.co.uk (F. Charles)

${ }^{*}$ Corresponding author

\section{To cite this article:}

Tembe-Fokunang Estella, Fokunang Charles, Hoare Gary, Salwa Barkwan, Ngameni Bathelemy, Tsague Marthe, Paul Tomkins, Nwabo Kamdje Armel Herve, Ngadjui Bonaventure. Evaluation of the Cytotoxicity of Two Cameroonian Herbal Plants of Genus Triumfetta rhomboidea and Dorstenia elliptica Using the MTT and Neutral Red Assays. Journal of Diseases and Medicinal Plants.

Vol. 3, No. 6, 2017, pp. 97-103. doi: 10.11648/j.jdmp.20170306.11

Received: October 22, 2017; Accepted: November 6, 2017; Published: December 13, 2017

\begin{abstract}
The use of herbal plants in Cameroonian ethno-medicine has been gained some importance in the treatment of various illnesses and many studies on these plants well documented. Hundreds of plant species, and their extracts, are used in developing countries to treat numerous diseases despite the fact that only a small number are approved for therapeutic use by the FDA. For instance, some species of the Triumfetta rhomboidea and Dorstenia elliptica genus have been used in the treatment of infectious diseases, abdominal pain and as anti-inflammatory agents. However, the cytotoxic effects of these plants have not been studied in detail, nor have their molecular structures been identified. The study objective was to investigate the cytotoxic effects of these medicinal plants using both MTT and neutral red assays. This was experimental analytical studies conducted with two herbal plants identified by the national herbarium centre for authentication. To determine the cytotoxic effects of the plant species, Hep G2 cells were exposed to extracts taken from plant species at concentrations of $0.1,1,10$ and $100 \mu \mathrm{g} / \mathrm{ml}$ and the cytotoxic effects determined using both MTT and Neutral Red assays. Using both MTT and Neutral Red assays, the cytotoxicity of each plant species was determined. Cells treated with all other extracts of the plant species, cytotoxic effects were observed in at least one concentration tested. Results obtained for the MTT assay for cells treated with various concentrations of the methanol crude extract of the leaf of T. rhomboidea and Dorstenia elliptica showed a significant difference between control samples and those treated with $1 \mu \mathrm{g} / \mathrm{ml}, 10 \mu \mathrm{g} / \mathrm{ml}$ and $100 \mu \mathrm{g} / \mathrm{ml}$ of sample. In addition, significant differences were observed between samples treated with $0.1 \mu \mathrm{g} / \mathrm{ml}$ and $10 \mu \mathrm{g} / \mathrm{ml}$ and $100 \mu \mathrm{g} / \mathrm{ml}$ of sample. Results obtained for the neutral red assay for this species showed no significant difference in absorbance levels between control samples, and those treated with any concentration of the plant extract tested. However, significant differences were detected for this species in the neutral red assay between samples treated with $0.1 \mu \mathrm{g} / \mathrm{ml}$ of extract and $10 \mu \mathrm{g} / \mathrm{ml}$ extract, in addition to significant differences being detected in samples treated with $0.1 \mu \mathrm{g} / \mathrm{ml}$ and $100 \mu \mathrm{g} / \mathrm{ml}$ of extract. Other plant species tested during this study may not be suitable for use in medicine because of their potential cytotoxic effects.
\end{abstract}

Keywords: Cytotoxicity, MTT, NR, Dorstenia, Triumfetta 


\section{Introduction}

Plants have a vital role to play in maintaining the environment, and sustaining life on the earth. The primary role of green plants is to take in the carbon dioxide produced on earth, and use this to produce food to feed them, and produce oxygen to discharge so that it can be used by all other non-green organisms $[1,2,3]$. Indeed, if this photosynthetic process was interrupted on a large-scale basis, then life on earth would not survive, so plants play a role in the existence and survival of other organisms. In addition, by taking in carbon dioxide, plants also help to reduce levels of carbon dioxide in the atmosphere, hence reducing pollution levels. An additional role of plants is to act as a main component of food webs, as they provide food for herbivores, and ultimately carnivores, while also having a role to play in the economy, as plants can be used in food, medicine, transportation, construction and fuel [4].

\subsection{Plants and Medicine}

For thousands of years, plants have been recognised to play a therapeutic role in curing diseases and infections, and currently, there is a wide range of herbal remedies available in health food shops and other outlets, which many people are using to treat numerous problems, despite the fact that most herbal and plant remedies have not been approved for use by the FDA [5]. It is now realised that the therapeutic effects of plant products are mainly due to the phytochemicals found in these plants, as many are known to have a pharmacokinetic or pharmacodynamic interaction with certain drugs $[1,6]$. Because of these potential benefits of using plants in medicine, many species are now being analysed to identify the phytochemicals found in them.

Despite this, however, the safety of using plants in medicine is continuously being reviewed, and much work is being done to determine not only the efficacious effects of plants, but also their potential harmful effects [7]. Although it has been purported by some herbal remediests that the use of plants as herbal medicine is safe due to the fact that it is a "natural" substance, there have been a number of publications that indicate otherwise $[2,8]$. Some herbal medicines are known to have resulted in severe side-effects after ingestion, which may be due to the toxic properties of the herbs or plants used, while the interactions of the plants or herbal medicine with other drugs being used by the patient can also lead to adverse effects $[9,10]$. For example, a number of severe effects, including heart attack, stroke and even death have been reported following the use of products containing Ma huang (ephedrine) and kola nut due to the interaction of the caffeine in the kola nut and the ephedrine [11]. Numerous members of the Ficusspecies have been documented to be used for both food and medicine, and their use has been most widely documented in the Middle East, where many members of this species are known to grow $[3,12]$.

\subsection{Study Test Medicinal Plants}

For this study, a number of species from the genus Triumfetta rhomboidea and Dorstenia elliptica were collected from forest in Cameroon. Extracts from the stem, leaf, bark and trunk were taken from these plants using a number of different extraction solvents. In addition this study also aimed to determine the cytotoxic effects of each of these plant species on a human hepatocellular carcinoma cell line, HEP G2. Extracts from these plant species were incubated on Hep G2 cells for 24hrs, at a number of different concentrations, and their cytotoxic effects determined using both MTT and neutral red assays.

\subsubsection{Triumfetta rhomboidea}

T. rhomboidea is a member of the Tiliaceae family, and is more commonly known as $T$. burr. This shrub usually grows to about $1.5 \mathrm{~m}$ tall, while its leaves can vary in size and are ovate to broadly ovate in shape. Small, yellowcoloured flowers are found on this plant, and can have 1015 stems per flower. In addition, the fruits of this plant are covered with satellite hairs. This plant is found mostly in the tropics. This plant had an important role to play in ancient medicinal therapy, and is still used in some parts of the world for its medicinal properties [5, 13]. The most commonly used therapeutic parts of the plant include the flower, leaves, bark, root and fruit [14]. The root of the plant has been traditionally used as an aphrodisiac, and has also been used in the treatment of dysentery as a diuretics $[11,15]$. Intestinal ulcers have been treated with the pounded roots of this species $[3,16]$. The flowers and fruits of T. rhomboidea have been used in gonorrhoea and leprosy treatment [9], while in East Africa powdered leaves of the plant are used in the treatment of anaemia [14, 17]. Essential oils isolated from T. rhomboidea have been shown to possess antimicrobial activity [17], while its methanol extracts have also been shown to have antioxidant and antitumour activity in vivo $[2,18]$.

\subsubsection{Dorstenia elliptica}

Dorstenia elliptica genus have been used in the treatment of infectious diseases, abdominal pain and as antiinflammatory agents. However, the cytotoxic effects of these plants have not been studied in detail, nor have their molecular structures been identified. The genus Dorstenia from phytochemical screening has been shown to contain flavonoids, coumarines, terpenoids with tested antioxidants, anticancer, antibacterial and antiulcer and cytoprotective properties [20-23]. Despite its promising biological activities there is a gap of information on its safety profile for potential use in the Cameroonian pharmacopoeia.

\section{Materials and Methods}

\subsection{Plant Material}

A number of species from the genus, Dorstenia and Triumfetta genus were tested during this study. All plant species were collected from the Upper Nyong forest reserve in Cameroon and identified for authentication at the National 
Herbarium of Yaoundé, Cameroon. The species studied are outlined in Table 1 to show the parts of the plant that were isolated and the fractions tested.

Table 1. Parts of the plant isolated from D. elliptica.

\begin{tabular}{lll}
\hline & Part of Plant Isolated & Fraction \\
Dorstenia & Leaf & DE1 (details not specified) \\
elliptica & roots & DE6 (details not specified) \\
& leaf & DE13 (details not specified) \\
& stem & DE14 (details not specified) \\
& Part of Plant Isolated & Methoxyumbelliform molecule \\
& Stem & Fraction \\
Triumfetta & Stem & Hexane \\
rhomboidea & Stem & n-Butanol \\
& Leaf & Crude Extract Methanol \\
& Stem & Crude Extract Methanol \\
\hline
\end{tabular}

\subsection{Cell Culture}

In this study, a human hepatocellular carcinoma cell line, Hep G2, was used to test the toxicity of each plant species. One sample from each plant species was incubated on HepG2 cells at concentrations of $0.1 \mu \mathrm{g} / \mathrm{ml}, 1 \mu \mathrm{g} / \mathrm{ml}, 10 \mu \mathrm{g} / \mathrm{ml}$ and $100 \mu \mathrm{g} / \mathrm{ml}$ to determine if this fraction inferred any cytotoxic effects to the cells. Results were compared to control samples. The plant species tested, parts of the plant tested and extract solvent are outlined in table 2. Cultures of this cell line were kindly supplied by the laboratory technicians.

Table 2. The plant species tested for cytotoxicity and the parts of the plant and fractions tested on Hep G2 cells.

\begin{tabular}{llll}
\hline Triumfetta & rhomboidea & Leaf & Crude extract methanol \\
Dorstenia & elliptica & Leaf & DE1 (details not specified) \\
\hline
\end{tabular}

\subsubsection{Subculture of Cells}

The culture medium was removed from the flask and a solution of $0.25 \%$ trypsin $/ 1 \mathrm{mM}$ EDTA was added. Cells were incubated at $37^{\circ} \mathrm{C}$ at $5 \% \mathrm{CO}_{2}$ for 10 minutes, and an equal volume of medium was added to deactivate the trypsin. The culture was transferred to a $50 \mathrm{ml}$ conical tube and centrifuged at $2000 \mathrm{rpm}$ for 5 minutes. Cells were resuspended in medium and seeded into T-175 flasks. Cultures were replenished with medium every 3-4 days and passaged again when $90-95 \%$ confluent.

\subsubsection{Preparation of Cells from a Monolayer Culture for Counting}

Cells were first viewed to assess their morphology and their degree of confluence. Following this, medium was removed from the flask, and $3 \mathrm{mls}$ phosphate buffered saline (PBS) was added to the flask, which was gently shaken to wash the cells. The PBS was removed, and 6mls trypsin-EDTA added to the flask, which was again gently shaken to soak the cells. The flask was then placed in an incubator $\left(37^{\circ} \mathrm{C}, 5 \% \mathrm{CO}_{2}\right)$ for $3-4$ minutes, and upon removing the flask the cells were observed under the microscope to assess their degree of detachment. When cells were fully detached from the flask, $6 \mathrm{mls}$ fresh medium was added to the cells, mixed well and the cell suspension was then removed and placed in a universal. The cells were pelleted by centrifugation at 2000rpm for 5 minutes. The supernatant was then removed, $2 \mathrm{mls}$ fresh medium was added to the universal and the pellet was re-suspended in this fresh medium.

To count the cells, the haemocytometer and cover-slip were washed in $70 \%$ ethanol and wiped dry. The slide and cover-slip were moistened and placed in contact so that both grids on the slide were covered. $0.2 \mathrm{mls}$ was taken from the cell suspension prepared in the universal, and mixed with $0.3 \mathrm{mls}$ PBS and $0.5 \mathrm{mls} 0.4 \%$ trypan blue (viability dye). This mixture was allowed to stand for 5 minutes. Following this, a small volume of the dyed cells was taken and added to both channels of the haemocytometer slide using a micropipette. All colourless cells were counted using the 5 large squares of the haemocytometer, and this number was then placed into the following formula to determine cell density.

$$
\text { Cell Count: } \frac{10^{4} \mathrm{x} \text { no. cells } \mathrm{x} \text { dilution factor }}{\text { No squares counted }}
$$

\subsection{Toxicity Assays}

\subsubsection{MTT Assay}

The MTT assay was used to determine the proliferation rate of cells treated with plant extracts at different concentrations taken from a two different plant species. In this assay, metabolically active cells converted yellow tetrazolium salt MTT to purple formazan crystals, and the number of viable cells in the population was proportional to the amount of formazan produced.

Cells were seeded in a 96-well plate at the required density, and incubated for $24 \mathrm{hrs}\left(37^{\circ} \mathrm{C}, 5 \% \mathrm{CO}_{2}\right)$ to allow the cells to adhere. $10 \mu 1$ plant extract chemical was added to the cells at concentrations of $0.1,1,10$ and $100 \mu \mathrm{g} / \mathrm{ml}$. The untreated cells (control) received medium only. The plate was then incubated for $24 \mathrm{hrs}\left(37^{\circ} \mathrm{C}, 5 \% \mathrm{CO}_{2}\right)$. The chemical and medium were both removed from the cells, which were then washed with $100 \mu 1$ PBS. This was removed from the cells, and $100 \mu \mathrm{l}$ fresh medium and $10 \mu \mathrm{l}$ of MTT to each well and incubated for 3 hours. After $3 \mathrm{hrs}, 100 \mu \mathrm{l}$ DMSO was added, and the plate was gently shaken to solubilise the dye. The absorbance was then read at 540nm using a BiotekMultiwell Plate Reader. A set of negative controls (untreated cultures) was used in each experiment, and all experiments were run in triplicates.

\subsubsection{Neutral Red Assay}

Cells were seeded in a multi-well plate at the required density, and the plate was incubated for $24 \mathrm{hrs}\left(37^{\circ} \mathrm{C}, 5 \%\right.$ $\mathrm{CO}_{2}$ ) to allow the cells to adhere. $10 \mu \mathrm{l}$ plant extract chemical was added to the cells at concentrations of $0.1,1,10$ and $100 \mu \mathrm{g} / \mathrm{ml}$. As a control, medium was added to the cells (with no plant extract). The plate was then incubated for $24 \mathrm{hrs}$ $\left(37^{\circ} \mathrm{C}, 5 \% \mathrm{CO}_{2}\right)$. The medium and plant extract was then removed from the cells, and replaced with $100 \mu 1$ neutral red medium. The plate was then incubated $\left(37^{\circ} \mathrm{C}, 5 \% \mathrm{CO}_{2}\right)$ to allow uptake of dye into the cells. The neutral red medium was then removed from all wells, which were washed with PBS that was then removed. $100 \mu$ l neutral red extract was 
added to the cells, and incubated for 15 minutes at room temperature. The absorbance was then read at $540 \mathrm{~nm}$ using a BiotekMultiwell Plate Reader.

Hep G2 cells were treated with extracts taken from each of the species tested to determine if they resulted in any cytotoxic effects to this cell line. Concentrations of $0.1,1,10$ and $100 \mu \mathrm{g} / \mathrm{ml}$ of each plant species were prepared and dissolved in methanol, and incubated on the cells for $24 \mathrm{hrs}$. The toxicity of each species was determined carrying out both MTT and Neutral Red assays. For the control, cells were incubated with medium only for $24 \mathrm{hrs}$.

\subsection{Statistical Analysis}

Results obtained for both MTT and Neutral Red assays were analysed statistically using student T-tests. Absorbance levels for control samples were compared to the absorbance levels obtained for each concentration of extract used to determine if there were any significant differences between absorbance levels. In addition, results obtained for the concentrations of the extracts used were compared to each other to determine if there were any significant differences between the different concentrations.

Student T-tests were performed on the results obtained to determine if any significant differences could be detected between control samples, and those treated with plant extract, and to determine if there were any significant differences between the various concentrations of plant extract used in the study.

\section{Results}

\subsection{Triumfetta rhomboidea MTassay Results}

Results obtained for the MTT assay for cells treated with various concentrations of the methanol crude extract of the leaf of $T$. rhomboidea showed a significant difference between control samples and those treated with $1 \mu \mathrm{g} / \mathrm{ml}, 10 \mu \mathrm{g} / \mathrm{ml}$ and $100 \mu \mathrm{g} / \mathrm{ml}$ of sample Figure 1 In addition, significant differences were observed between samples treated with $0.1 \mu \mathrm{g} / \mathrm{ml}$ and $10 \mu \mathrm{g} / \mathrm{ml}$ and $100 \mu \mathrm{g} / \mathrm{ml}$ of sample (Figure 1).

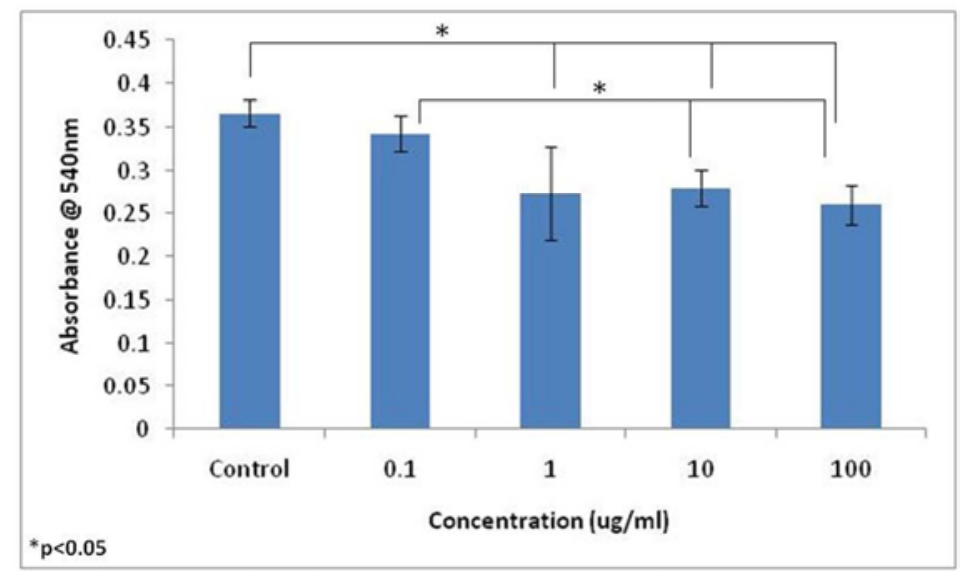

Figure 1. MTT assay results for Hep G2 cells exposed to 0.1,1,10 and $100 \mu \mathrm{g} / \mathrm{ml}$ of the methanol crude extract of T. rhomboidea isolated from the leaf.

\subsection{T. rhomboideaNR Assay Results}

Results obtained for the neutral red assay for this species showed no significant difference in absorbance levels between control samples, and those treated with any concentration of the plant extract tested (Figure 2). However, significant differences were detected for this species in the neutral red assay between samples treated with $0.1 \mu \mathrm{g} / \mathrm{ml}$ of extract and $10 \mu \mathrm{g} / \mathrm{ml}$ extract, in addition to significant differences being detected in samples treated with $0.1 \mu \mathrm{g} / \mathrm{ml}$ and $100 \mu \mathrm{g} / \mathrm{ml}$ of extract (Figure 2).

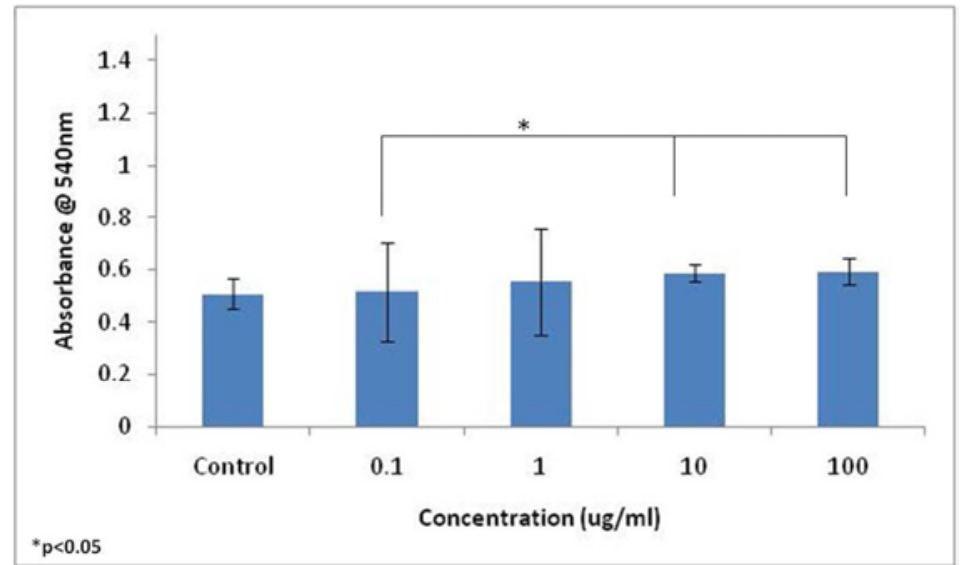

Figure 2. Neutral red assay results for HepG2 cells exposed to 0.1, 1, 10 and $100 \mu \mathrm{g} / \mathrm{ml}$ of the methanol crude extract of T. rhomboidea isolated from the leaf. 


\subsection{D. elliptica MTT Assay Results}

The DE1 fraction isolated from D. elliptica was also tested using HepG2 cells for its cytotoxic effects. However, no details were provided about this fraction. Results obtained using the MTT assay showed no significant difference in absorbance levels between control samples, and those treated with any concentration of the plant extract tested, and no significant difference between the various concentrations of plant extract tested (Figure 3). However, results obtained for the neutral red assay showed a significant difference in absorbance levels between control samples and those treated with concentrations of $0.1 \mu \mathrm{g} / \mathrm{ml}$ and $100 \mu \mathrm{g} / \mathrm{ml}$ of extract.

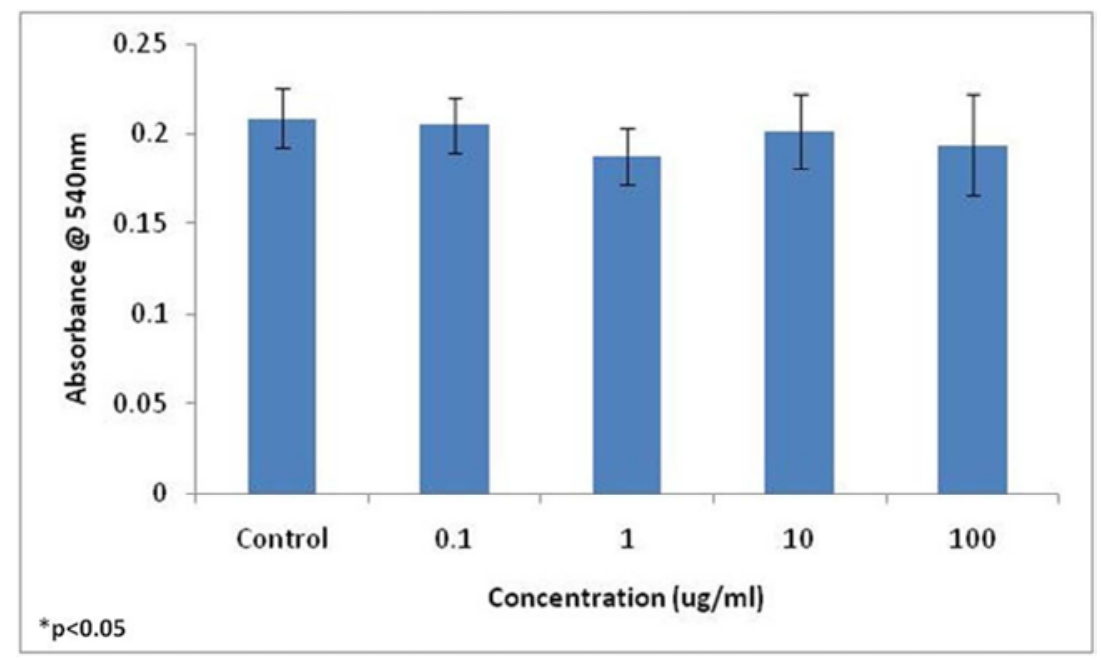

Figure 3. MTT assay results for Hep G2 cells exposed to 0.1, 1, 10 and $100 \mu \mathrm{g} / \mathrm{ml}$ of the DE1 fraction isolated from D. elliptica.

Significant differences in absorbance levels between the concentrations of $0.1 \mu \mathrm{g} / \mathrm{ml}$ and $10 \mu \mathrm{g} / \mathrm{ml}$ and $0.1 \mu \mathrm{g} / \mathrm{ml}$ and $100 \mu \mathrm{g} / \mathrm{ml}$ used on the cells were also seen using the neutral red assay (Figure 4). In addition, significant differences were observed between cells treated with $1 \mu \mathrm{g} / \mathrm{ml}$ and $100 \mu \mathrm{g} / \mathrm{ml}$ of extract, and cells treated with $10 \mu \mathrm{g} / \mathrm{ml}$ of extract and $100 \mu \mathrm{g} / \mathrm{ml}$ of extract (Figure 4).

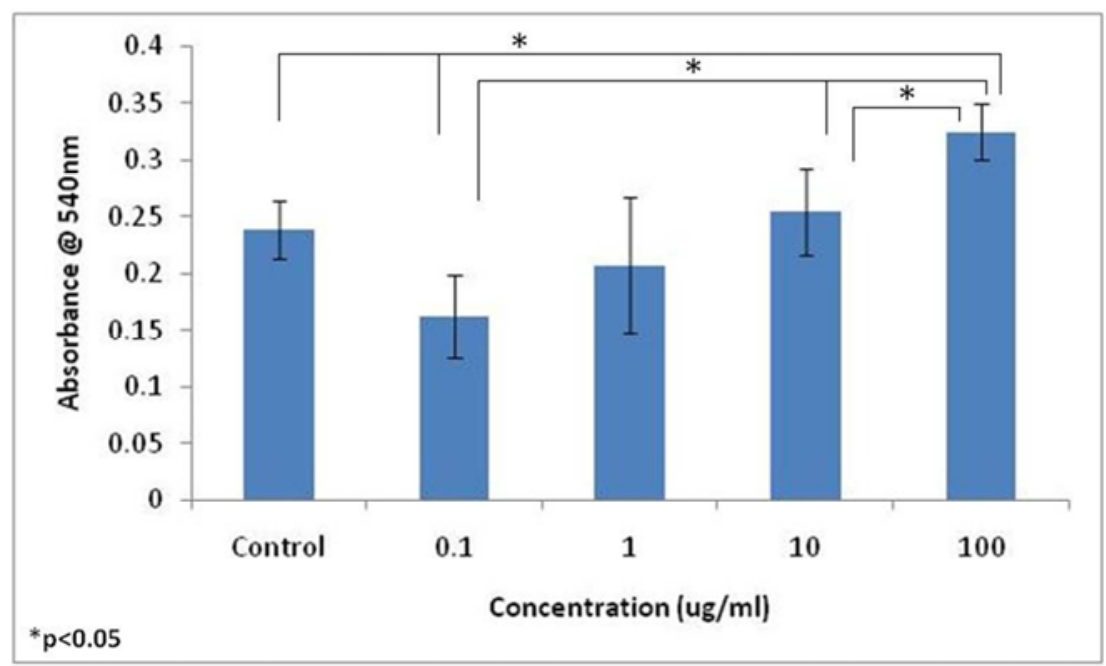

Figure 4. Neutral red assays results for Hep G2 cells exposed to $0.1,1,10$ and $100 \mu \mathrm{g} / \mathrm{ml}$ of the DE1 fraction isolated from D. elliptica.

\section{Discussion}

In order to determine the cytotoxic effects of each of the species, a number of concentrations were tested on HepG2 cells, and their cytotoxic effects determined using both MTT and Neutral Red assays. HepG2 cells were also treated with extracts of T. rhomboidea to determine its cytotoxicity on this cell line. MTT assay results showed that extracts of this species does result in significant cytotoxic effects on HepG2 cells at concentrations of $1 \mu \mathrm{g} / \mathrm{ml}, 10 \mu \mathrm{g} / \mathrm{ml}$ and $100 \mu \mathrm{g} / \mathrm{ml}$, while significant differences in cytotoxicity levels were observed in cells treated with 10 and $100 \mu \mathrm{g} / \mathrm{ml}$ of sample when compared to cells treated with the lower concentration of $0.1 \mu \mathrm{g} / \mathrm{ml}$ of plant extract. Neutral red assay results showed no significant differences in cytotoxicity levels between control samples and those treated with any concentration of plant extract tested, but similar to results obtained for the MTT assay, significant differences in cytotoxicity was 
observed in cells treated with 10 and $100 \mu \mathrm{g} / \mathrm{ml}$ of extract compared to cells treated with the lower concentration of $0.1 \mu \mathrm{g} / \mathrm{ml}$ of extract. These results indicate that $T$. rhomboidea may not be a suitable plant for medicinal purposes due to its cytotoxic effects on the HepG2 cell line, unless used at very low concentrations. The root of Triumfetta plant has been traditionally used as an aphrodisiac, and has also been used in the treatment of dysentery as diuretics $[11,19]$. Intestinal ulcers have been treated with the pounded roots of this species [20]. The flowers and fruits of T. rhomboidea have been used in gonorrhoea and leprosy treatment [21], while in East Africa powdered leaves of the plant are used in the treatment of anaemia [14, 22]. Essential oils isolated from $T$. rhomboidea have been shown to possess antimicrobial activity $[17,21]$, while its methanol extracts have also been shown to have antioxidant and anti-tumour activity in vivo $[18,22]$.

The cytotoxicity of $D$. elliptica was also examined using HepG2 cells, and MTT assay results indicated that no cytotoxicity was observed in samples treated with a range of concentrations of plant extract compared to control samples. However, when the cytotoxic effects of this plant species were examined using neutral red assays different results were observed. It was found that a significant difference in cytotoxic effects was observed in samples treated with both $0.1 \mu \mathrm{g} / \mathrm{ml}$ and $100 \mu \mathrm{g} / \mathrm{ml}$ of extract when compared to control samples, but not samples treated with 1 and $10 \mu \mathrm{g} / \mathrm{ml}$ of extract, indicating that this experiment should be repeated to ensure that these results are accurate. In addition, significant differences in cytotoxic effects were observed in cells treated with $10 \mu \mathrm{g} / \mathrm{ml}$ and $100 \mu \mathrm{g} / \mathrm{ml}$ of plant extract compared to those treated with $0.1 \mu \mathrm{g} / \mathrm{ml}$ of plant extract, in addition to significant differences being observed in cell samples treated with $100 \mu \mathrm{g} / \mathrm{ml}$ of extract when compared to those treated with both 1 and $10 \mu \mathrm{g} / \mathrm{ml}$. These results indicate that higher concentrations of $D$. elleptica may result in cytotoxic effects, and so it may not be suitable for use as a medicinal plant.

Overall, the results of this project indicated that most of the plant species tested may not be suitable for use as medicinal plants due to the cytotoxic effects observed on HepG2 cells when incubated with fractions isolated from each species. The results obtained indicate that, if used as medicinal agents, low concentrations of each species should be used. However, much more research needs to be conducted to determine the suitability of these plant species as medicinal agents, and their use needs to be regulated by the WHO, FDA and other national agencies.

\section{Conclusion}

The two herbalplant species tested during this study may not be suitable for use in the Cameroonian pharmacopoeia as an improved traditional medicine because of their potential cytotoxic effects. However the promising biological activities of these plant of pharmaceutical importance needs a more high through put screening approach and purification of the compounds for advanced toxicity studies.

\section{References}

[1] Fokunang CN, Ngameni B, Guedje NM, Jiofack RT, J. Ngoupayo J, Tabi OY, Tembe-Fokunang EA, Salwa B, Tomkins P, et al. Development of antimalarial, antibacterial, anticancer and antitumour drugs from new chemical entities from plant sources.. Journal of Applied Science and Technology (JAST), 2011. Vol. 16, Nos. 1 \& 2, 2011, pp. 1523.

[2] Fokunang CN, Ndikum V, Tabi OY, Jiofack, R. B, Ngameni B, Guedje N. M, Tembe-Fokunang, E. A, Tomkins P, Barkwan S, Kechia, F, Asongalem E, Ngoupayou J, Torimiro, NJ, Gonsu KH1, Sielinou V, Ngadjui BT, Angwafor III F, Nkongmeneck A, Abena OM, Ngogang J, Asonganyi T, Colizzi V., Lohoue J, Kamsu-Kom. Traditional Medicine: Past, Present And Future Research And Development Prospects And Integration In The National Health System Of Cameroon. African Journal of Traditional Complementary and Alternative Medicine. (2011) 8(3):284-295 284.

[3] KamguiaGuifo HF, Fokunang CN, Ngameni B, Njinkio NBTembe-Fokunang EA. Effet Cytoprotecteur De L'extrait Aqueux Des Racines De Dorstenia Psilurus Sur L'ulcere Gastrique Chez Les Rats Males De La Souche Wistar. Health Sci. Dis 2011: Vol 12 (4) 195-206.

[4] Guedje NM, Tadjouteu F, Dongmo RF, Jiofack RBT, Tsabang $\mathrm{N}$, Fokunang CN, Fotso S. Medicine traditionelle Africaine (MTR) et phytomedicaments:Defis et strategies de development. Health Sciences and Disease 2012:12 (3).122146. ISBN1684-2782.

[5] Fokunang CN, Mejane NN, Noumie E, Ngameni B, Gonsu HK, Kechia FA, Awousong KP, Guedge NM, Jiofack RT, Fokunang-Tembe EA, Ngoupayo J, Ndikum V, Tabi OY, Ngadjui BT.2011. In vitro evaluation of the anti-bacterial properties of crude extracts of Dorsteniamannii (Moraceae). Journal of Microbiology and Antimicrobials 2012. Vol. 4(6), pp. $\quad 88-95, \quad$ http://www.academicjournals.org/JMA. DOI:10.5897/JMA10.051 ISSN 2141-2308

[6] Fouondo M, Nyangono B, Fokunang CN, Ngameni B, Fernande, Ngondi JL., Tembe-Fokunang EA,. Oben JE. Evaluation of Phytochemical screening and in vitro antioxidant activity of ethanolic and hydroethanolic extracts of the fruits and twigs of Ficusovatavahl (Moraceae). Health Sciences and Disease 2012:12 (3) 105-110 ISBN1684-2782

[7] Ngameni, B., Kuete, V., Simo, I. K., Mbaveng, A. T., Awoussong, P. K., Patnam, R., Roy, R., and Ngadjui, B. T.. Antibacterial and antifungal activities of the crude extract and compounds from Dorstenia turbinate (Moraceae). S. Afr. J. Bot.2009:75, 256-261.

[8] Ngameni, B., Touaibia, M., Belkaid, A., Ambassa, P., Watchueng, J., Patnama, R., Ngadjui, B. T., Annabi, B., and Roy, R. Inhibition of matrix metalloproteinase- 2 secretion by chalcones from the twigs of Dorsteniabarteri bureau. Arkivoc 2007., 9, 91-103.

[9] Ngameni B, Touaibia M, Patnam R, Belkaid A, Sonna P, Ngadjui BT, Annabi B, Roy R. Inhibition of MMP-2 secretion from brain tumor cells suggests chemopreventive properties of a furanocoumarin glycoside and of chalcones isolated from the twigs of Dorsteniaturbinata. Phytochemistry2006. 67, 2573-2579. 
[10] Kuete V, Efferth Cameroonian medicinal plants: pharmacology and derivednatural products. Frontiers in Pharmacology. 2010, 1:(123) 1-19. doi: 10.3389/fphar.2010.00123. www.frontiersin.org

[11] BushR, Holloway SY, Allen L, Greyber KR. Adverse interactions between herbal and dietary substances and prescription medications: a clinical survey. AlternTher Health Med. 2007 13, 30-35.

[12] Devmurari GJ. Antibacterial Activity and Phytochemical Study of Ethanolic Extract of Triumfetta Rhomboidea Jacq. International Journal of PharmTech Research2010.2, 11821186.

[13] Gbeassor K, Koumaglo A, Amegbo P. In vitro anti-malarial activity of six medicinal plants. Phytother Res. 1999. 4, 115117.

[14] Kubmarawa A, Enwerem O. Preliminary Phytochemical and Antimicrobial Screening of 50 Medicinal Plants from Nigeria. Journal of Biotechnology2006, 7:1690-1696.

[15] Kuete V, Kamga, Sandjo P, Ngameni B, Poumale B, Ambassa, Ngadjui B. Antimicrobial activities of the methanol extract, fractions and compounds from Ficuspolita Vahl. (Moraceae). BMC Complement Altern Med 2012 11, 6-15.

[16] Lee. Research and future trends in the pharmaceutical development of medicinal herbs from Chinese medicine. Public Health Nutr 200. 3, 515-522.

[17] Mevy BR, Rabier D, Ruzzier R, Millogo V. Composition and Antimicrobial Activities of the Essential Oils of Triumfetta rhomboidea Jacq. Flavour and Fragrance Journal.2006 21, 8083.

[18] Rout N, Pandam MI. Ethnomedicinal plants used to cure different diseases by tribal's of Mayurbhanj district of North Orissa. Ethno-Med. 2009 3, 27-32.

[19] Sirisha S, Sreenivasulu U, SangeetaC.. Antioxidant Properties of Ficus Species - A Review. International Journal of PharmTech Research. 2010 2, 2174-2182.

[20] Sivakumar K, Sivakumar N, Nethaji P, Vijayabaskaran B, Bukkawer J, Parvathi S. Antitumor and Antioxidant Activities of Triumfetta rhomboidea against Dalton's Ascites Lymphoma Bearing Swiss Albino Mice. Research Journal of Medicinal Sciences. 2008. 2, 203- 208.

[21] Starr L. 2003. Ficuselastica: Indian Rubber Tree. United Sates Geologial Survey - Biological Resources Division 2003, 312PP.

[22] Uttara M. Evaluation of antioxidant activity of aqueous extract bark of Ficusglomerata. Research Journal of Pharmacy and Technology 2008 1, 537-538. 